8. Kukhaleishvili, G. (2019). The effects of Brexit: What challenges await the UK after leaving the EU (23.12.2019). 112 channel. URL: https://ua.112.ua/statji/naslidky-brekzitu-yakivyklyky-chekaiut-na-velyku-brytaniiu-pislia-vykhodu-z-yes-519676.html

9. Levytska, I. Great Britain leaves the EU today - consequences for Ukraine and Europe (01/31/2020), URL: https://gazeta.ua/articles/posuti/_velika-britaniya-sogodni-vihodit-iz-es-naslidki -dlya-ukrayini-ta-europe / 949378

10. Molchakov, N. Yu. (2016). Scotland 's constitutional status through the lens of British regionalism. To the next anniversary of the Union Act of 1707 Moscow. Journal of International Law, No. 2, 161-173.

11. Sharov, O. M. (2019). Brexit: Pros and Cons for Global Geoeconomics. URL: https://niss.gov.ua/sites/default/files/2019-10/tezi_sharov-o.m.pdf

12. Brexit: the price of one referendum. In the Money... (03/04/20190. Ukrinform. URL: https://www.ukrinform.ua/rubric-world/2673704-brexit-cina-odnogo-referendumu-v-grosah.html

13. Clarke, H. B., Goodwin, M., Whiteley, P. (2017). Brexit: Why Britain Voted to Leave the European Union. Cambridge: Cambridge University Press. 272.

14. Evans, G., Menon, A. (2017). Brexit and British Politics. London: Polity. 140.

15. Haughton, T., Copsey, N. (2014). Farewell Britannia? «Issue Capture» and the Politics of Cameron's EU Referendum Pledge. Journal of Common Market Studies, 52 (51). P. 74-89. DOI: 10.1111/jcms. 12177 Press. 208.

16. Lepenies, P. (2016). The Power of a Single Number. New York: Columbia University

17. Oliver, C. (2017). Unleashing Demons: The Inside Story of Brexit. London: Hodder.448.

Матеріал надійшов до редакції 16.01.2020 р.

УДК 323:173.

\title{
Володимир Лісовський,
}

кандидат політичних наук, доцент,

доцент кафедри соціально-гуманітарних дисциплін,

Національний університет кораблебудування

імені адмірала Макарова

(Миколаїв, Україна)

https://orcid.org/0000-0003-4101-7290

lisovsky.vn@gmail.com

https://doi.org/10.29038/2524-2679-2020-01-148-165

\section{ВИНИКНЕННЯ СЕПАРАТИЗМУ ТА ЙОГО РОЛЬ У ВНУТРІШНЬОПОЛІТИЧНИХ ПРОЦЕСАХ ПОЛІЕТНІЧНИХ ДЕРЖАВ}

У статті проаналізовано концептуальний підхід до дослідження сепаратизму, що передбачає територіально-політичний рух, мета котрого - відокремлення від країни частини ї̈ території та створення незалежної держави. Сепаратизм призводить до порушення єдності, суверенітету й територіальної цілісності держави, принцииу

(C) Лісовський В., 2020 
непорушності кордонів. Уточнено сутність поняття досліджуваного феномену. Визначено терміни «сепаратизм» $i$ «політика сепаратизму», виявлено специфіку сепаратизму в контексті інших етнооб'єднавчих $i$ етнороз'єднавчих рухів. Виокремлено функиіональні моделі політики сепаратизму, щзо проводяться 3 урахуванням характеру стратегічних иілей суб'єктів сепаратизму й типу панівних у певний історичний період міжнародних відносин. Розкрито суть подвійної природи сепаратизму, його специфіку на двох рівнях - внутрішньополітичному та міжнароднополітичному. Звертається увага на регіональні різновиди сепаратизму: західноєвропейський (нараховує вісім проявів сепаратизму); східноєвропейський (13 проявів сепаратизму); ісламський (шість проявів сепаратизму); азіатський (14 проявів сепаратизму); африканський (шість проявів сепаратизму); американський (чотири прояви сепаратизму). Доведено, що сепаратизм має глибокі історичні корені, котрі пов'язані з існуванням суперечності між історичними традиціями взаємодіі держав на принципах державного суверенітету й непорушності кордонів, з одного боку, та принципах права начій на самовизначення, щзо утвердилися в практииі міжнародних відносин і передбачають можливість формування незалежних держав, осередків сепаратизму у світі, накладають відбиток на політико-географічне положення території. До вироблення конкретних рекомендацій стосовно зниження ризиків сепаратизму може призвести розуміння механізмів ияього впливу.

Ключові слова: сепаратизм, сепаратистський рух, етнічні конфлікти, сецесія, іредентизм, етнічна спільнота, національна ідентичність.

\section{1. ВСТУП}

Постановка проблеми. Активізація процесів глобалізації, трансформації політичних та економічних режимів у світі на поч. XXI ст. зумовили посилення сепаратистських рухів. Сепаратизм, будучи суперечливим суспільнополітичним явищем, являє собою одну з найскладніших та найактуальніших проблем світового співтовариства, тому потрібно досліджувати його роль у міжнародних відносинах. Виникнення цих суспільно небезпечних явищ у світі зумовлені активізацією процесів глобалізації, трансформацією політичних й економічних режимів. Це дасть можливість уникнути спекуляцій самим поняттям сепаратизм. Окрім того, інтенсивність проявів явища дає змогу говорити про рівень його загрози державній цілісності. Коріння етнічних конфліктів і сепаратистських рухів найчастіше міститься в процесі історичного освоєння території. Будь-який етнос формується на певній території, яка виступає основою його походження як соціокультурної системи та тлом протікання етнічних процесів. Етнічні й етноконфесійні конфлікти часто стають підгрунтям сепаратизму в різних його варіаціях. I етнічні конфлікти, і сепаратизм належать до територіальних проблем, що робить їх об'єктом дослідження географів. Для українських географів актуальність таких досліджень підсилюється наявністю проявів сепартизму в Україні, що призвели до окупації частини державної території та збройних конфліктів, що перебувають в активній фазі [18].

Мета дослідження - аналіз визначення сепаратизму як соціальнополітичного явища, яке у своєму розвитку пройшло декілька стадій і на різних етапах супроводжувалося вимогами різного ступеня радикальності, що 
потребує виявити ознаки й форми прояву цього феномену, його кількісноякісних показників. інформаційних викликів для України в умовах російськоукраїнського конфлікту, дослідження передумов їх виникнення та умов протистояння агресивному інформаційному проникненню в інформаційнокомунікаційний простір нашої держави.

\section{2. РЕЗУЛЬТАТИ ДОСЛІДЖЕННЯ}

У науковій літературі немає єдиного підходу щодо трактування поняття «сепаратизм». Констатовано відсутність конвенціонального знання щодо сутності сепаратизму, що можна пояснити багатоаспектністю самого досліджуваного явища й наявністю різних методологічних позицій, які покладено в основу наукових досліджень представників різних наук. Сепаратизм розглядається як етнополітичний процес, який являє собою сукупність стратегій і дій сепаратиської держави й сепаратистів - національної меншини в складі поліетнічної держави, яка прагне увійти до складу сусідньої держави на основі етнічної й культурної спорідненості. Як довготривала діяльність сепаратистських рухів, так і кожен новий спалах сепаратизму в різних куточках світу викликають до себе посилену увагу. Національні держави та наднаціональні утворення ставляться до них насторожено, локальні ж сепаратистські рухи в кожному випадку, який завершився хоча б частковим задоволенням вимог сепаратистів, прагнуть побачити сприятливий для себе прецедент. Науковці намагаються пояснити причини активізації відцентрових політичних процесів, класифікувати їх, дати морально-правову оцінку. Для цього активно досліджується масив міжнародно-правових документів, здійснюється збір й аналіз багатого емпіричного матеріалу. Щоправда, дослідження ускладнюється необхідністю враховувати подвійні стандарти, якими керуються провідні держави світу в ставленні до різних випадків самовизначення. Понять, які позначають відцентрові рухи, досить багато - це «сепаратизм», «етнічний сепаратизм», «іредентизм», «сецесія» й «сецесіонізм». Його визначають і як спосіб розв язання проблеми, і як рух за територіальне відокремлення, і як політика та практика діяльності суспільно-політичних рухів. Сепаратизм доцільно характеризувати як етнополітичний рух, ініційований меншинами-сепаратистами, мета якого - вихід зі складу поліетнічної держави й приєднання до спорідненої держави. Сепаратизм виступає формою етнічного уніонізму, але, на відміну від паннаціоналізму, створює загрози для територіальної цілісності суверенних держав. Прихильність національних меншин в Україні до сусідніх держав деякою мірою спричинена неефективною етнополітикою, яка не призвела до формування єдиної загальнонаціональної ідентичності. Наукові дослідження етнічних конфліктів та сепаратизму доводять неоднозначність і складність цих явищ. Науковий інтерес до сепаратизму посилився в другій половині ХХ ст., що зумовлено активними державотворчими процесами у різних регіонах світу, початком деколонізації, поступом демократичних перетворень. Вивчення сепаратизму ще більше активізувалось у 1990-ті роки й було викликане 
розпадом країн соціалістичного табору в Східній Європі, де дуже гостро постала проблема роздільності народів. Аналіз явищ і подій, безпосередньо пов'язаних 3 дезінтеграційними процесами, свідчить про те, що найпоширенішою формою сепаратизму в міжнародній практиці $\epsilon$ етнічний (етнотериторіальний), який за десятиліття змінив устрій різних держав i загалом - політичну карту світу. Під впливом етнічного сепаратизму відбувся розпад найбільших у сучасній історії поліетнічних держав Радянського Союзу i Югославії. Аналіз цієї проблематики є актуальним i для України, оскільки сепаратизм є загрозою для національної безпеки нашої держави. В Україні існує значна кількість сепаратистських тенденцій, які потребують теоретичного й практичного вивчення та дослідження. Тоді ж відбувся своєрідний ренесанс націоналістичної ідеї, і на початку XXI ст. націоналістичні ідеали, які вже тривалий час здійснюють потужний вплив на внутрішньополітичні процеси, більш активно спонукають держави до пошуку оптимальної моделі націотворення: або до реалізації формули «одна держава - одна нація» у варіанті політичної чи етнічної нації, або до формування багатонаціональної держави. У прямій залежності від обраного курсу перебувають етнічні групименшини, стосовно яких можуть проводитись або асиміляційна й дискримінаційна політики, або ж здійснюватися підтримка їх розвитку, спрямована на збереження самобутності цих груп. В усіх випадках цілком можливе виникнення в меншин прагнення до зміни свого статусу, у тому числі через приєднання до сусідньої держави, у якій домінує споріднена їм етнічна більшість. На цьому грунті виникає багато проблем, які стають предметами наукових досліджень, починаючи від попередження відцентрових тенденцій у поліетнічній державі й завершуючи оцінкою з боку міжнародної спільноти правомірності та моральності самого факту відокремлення. Мета етносоціальної спільноти на створення суверенної держави реалізується шляхом висунення сепаратистських вимог. Сепаратизм досить активно досліджується представниками різних країн, але досягти конвенціональності у визначеності цього поняття не вдається до сьогодні. Зазвичай у науковій літературі сепаратизм (від лат. sepaiatus - окремий) це теорія, політика й практика відокремлення, відділення частини території держави $з$ метою створення нової самостійної держави або одержання статусу широкої автономії [7].

Н.Горло пропонує власне визначення сепаратизму задля узагальнення у понятті «сепаратизм» інших, схожих за природою фактів, а саме автономізацію, сецесію, іредентизм: «дії і настрої частини населення держави, спрямовані на отримання більшого суверенітету у питаннях своєї життєдіяльності і (або) ідентичності». Сепаратизм - це і прагнення до відокремлення, відособлення, $\mathrm{i}$ радикальний політичний рух національних меншин, спрямований на відокремлення від держави, на території якої дана меншість компактно проживає, і створення своєї незалежної держави або автономного утворення 3 широким набором владних повноважень [6, с. 112].

В. Баранов виокремлює такі причини виникнення сепаратизму:

- економіко-географічні чинники. Намагання розвинених регіонів відокремитися більш від відсталих. Наприклад, Ліга Півночі в Італії, радикальні 
партії Каталонії. Бідні регіони найчастіше теж охоплені сепаратизмом. Їхні спільноти мають надію, що в окремій державі їм житиметься краще (наприклад Косово в Югославії). Африці.

- Расові чинники. Наприклад, сепаратизм білої меншості в Південній

- Етнічні чинники - найбільш поширена група причин сепаратизму. Суть ïх полягає в бажанні отримати автономію або розширити іï, домогтися статусу незалежної держави. Наприклад: Країна Басків в Іспанії, Абхазія й Південна Осетія в Грузії.

- Релігійні чинники. У Лівані, наприклад, домінуюче арабське населення розколото на велику кількість територіально замкнутих громад.

- Релігійно-етнічні чинники. Так, ірландці-католики в Ольстері бажають возз'єднатися 3 Ірландської Республікою, а мусульмани Кашміру - iз Пакистаном.

- Внутрішньополітичні чинники - прагнення регіональних еліт до влади, партійний, ідеологічний розкол країни (КНР і Тайвань, Північна та Південна Корея).

- Зовнішньополітичні чинники. Підтримка сепаратистів із боку «наддержав» і більш сильних сусідніх країн. Ця підтримка має різні мотиви: послаблення конкурента, опанування геополітично важливими районами й економікою окремих регіонів. Підтримка ззовні сприяла розпаду Югославії, Чехословаччини, СРСР.

- Ідеологічний чинник. Важливі аргументи сепаратистам дала доктрина самовизначення народів, що стала нормою міжнародного права в 1919 р. згідно з Версальською дипломатичною системою [3].

Політичний сепаратизм притаманний внутрішньодержавному рівню політичних відносин і є одним із його форм, поряд із культурою, економікою, екологією та ін. Але, на відміну від інших видів, саме політичний сепаратизм вимагає територіального відокремлення як єдиного способу розв'язання політичних проблем.

Прикладом такого типу $\epsilon$ ситуація в Криму, де окремі політики, зневажаючи закони України, висловлюють прагнення приєднатися до Росії. Зокрема, деякі російські політики, використовуючи антиукраїнські настрої, намагаються обгрунтувати поняття «народ Криму», що нібито має право на самовизначення. Цю ідею частково взяли на озброєння кримські сепаратисти для реалізації своїх радикальних прагнень щодо зміни державно-правного статусу автономії. Особливо яскраво це проявилося на виборах президента АР Крим 30 січня 1994 р., коли за лідера проросійських сил Ю. Мєшкова віддали голоси $73 \%$ виборців.

В. Свтух зазначає, що «зазвичай, сепаратисти розглядають державу як інституцію (форму) національної самоорганізації, у якій етнічна гомогенність і культурний консенсус становлять ідеологічну основу для політичного й територіального відділення частини держави та утворення нового етнополітичного організму (держави)» [10, с. 284]. Однак і в сучасних зарубіжній, і у вітчизняній політичних науках сепаратистськими визнаються 152 
навіть вимоги щодо здобуття широкої політичної автономії. В. Горенкін визначає сепаратизм як прагнення до відокремлення частини країни від іншої території держави (тобто політичний процес, тенденція), метою якого $\epsilon$ створення нової, незалежної держави, приєднання частини, що відокремилася, до іншої держави або отримання автономії в рамках наявної держави [5, с. 38].

Пріоритет у вивченні сепаратизму як за кількістю наукових досліджень, так i за якісним методичним наповненням уже тривалий час належить представникам зарубіжної політичної науки. Американський науковець Дональд Горовіц визначає сепаратизм і як спробу відокремлення території чи населення однієї держави із метою приєднання до іншої, i як спробу відокремлення території чи населення, що розділені між більш ніж однією державою, із метою подальшого їх об’єднання в єдину новоутворену державу [17, с. 10]. Про місце й значення сепаратизму в процесі державотворення влучно висловився П. Шредер, на думку якого, хоч національно-державне будівництво можна було б здійснювати без сепаратизму, сепаратизм неможливо проводити в умовах відсутності успішного державного будівництва [14].

Важлива специфічна ознака сепаратизму полягає в тому, що його ініціатором може бути як етнічна меншина, яка зазнає утисків у сусідній державі; так і етнічна більшість, яка прагне об’єднати всіх етнічних родичів в одній державі. Саме це зумовило появу таких визначень сепаратизму, які конкретизують ініціатора руху. Вихідні мотиви сепаратистів за своєю природою можуть бути політичними, економічними, етнічними, конфесійними, територіальними, у зв'язку 3 чим традиційно виділяють кілька видів сепаратизму. Із-поміж багатьох його видів найбільш поширеним у сучасному світі $\epsilon$ етнічний сепаратизм, оскільки чимало етносоціальних спільнот намагаються використати право на самовизначення й реалізувати його в тій чи іншій формі, зокрема створити власну державу. Специфіка етнічного сепаратизму полягає в тому, що він породжується багатьма причинами, зокрема, дискримінацією етнічної групи в політичній, економічній, релігійноконфесійній, культурній та інших сферах. Спосіб самовизначення через приєднання до сусідньої держави на основі етнічної спорідненості, тобто іредентизм, теоретично теж має право на існування, адже явище роздільності народів цілком об'єктивне й незаперечне. Але, на нашу думку, такий спосіб самовизначення виправдовується лише у випадку, коли етнічна група дійсно зазнає значних утисків і іiі перебування в складі держави неможливе, аж до загрози етноциду. У сучасний період найчастіше аргумент компактного проживання на території сусідньої держави етнічної групи, яку потрібно захистити, слугує прикриттям експансіоністських прагнень держави. Розмежування сепаратизму й іредентизму проведено багатьма науковцями.

В даній площині істотний вклад у розробку даного напрямку внесли праці українських вчених В. Андріяш, М. Басараба, К. Вітмана, В. Горбатенка, Н. Горло, В. Дівак, О. Кіндратець, В. Котигоренка, І. Кресіної, О. Кривицької, Л. Лойко, Г. Луцишин, О. Майбороди, Л. Нагорної, Ю. Остапця, I. Рафальського, Ю. Римаренка, С. Рябініна, О. Стогової, О. Стойко, Т. Халавки, 
В. Явір та інших. Слушною є думка щодо розуміння іредентизму у науковця Наталі Горло. У своєму дисертаційному дослідженні науковцем представлено авторський підхід щодо дослідження іредентизму. Акцентовано увагу на відсутність конвенціонального знання щодо сутності іредентизму, що можна пояснити багатоаспектністю самого досліджуваного явища і наявністю різних методологічних позицій, котрі лежать в основі наукових досліджень представників різних наук. Розроблено рекомендації щодо попередження i подолання деструктивного впливу іредентизму на політичні процеси у сучасному світі. Іредентизм розглядається як етнополітичний процес, який представляє собою сукупність стратегій i дій іредентистської держави й іреденти - національної меншини у складі поліетнічної держави, яка прагне увійти до складу сусідньої держави на основі етнічної i/чи культурної спорідненості. На іiі думку, таке визначення дозволяє врахувати різні аспекти іредентизму, який виступає і як об’єднавча політика іредентистської держави, $\mathrm{i}$ як рух національної меншини - іреденти. Тобто доцільно концептуально розрізняти «політику іредентизму» та іредентизм як різновид сепаратизму. Іредентизм може виникнути тоді, коли частина етносу вже сформувала власне державне утворення, у якому складає більшість (титульна держава), а інші його групи перебувають у складі сусідніх держав (іредента) [6, с.113].

В. Тураєв, характеризуючи націоналізм, виділяє три його види сепаратистський, реформаторський та іредентистський. Мета іредентистського націоналізму - об'єднання кількох держав чи приєднання частини однієї держави до іншої. Розмежування сепаратизму й іредентизму здійснено багатьма дослідниками. В. Тураєв, характеризуючи націоналізм, виділяє три його види сепаратистський, реформаторський та іредентистський. Мета іредентистського націоналізму - об'єднання кількох держав чи приєднання частини однієї держави до іншої [17, с. 83].

Серед дослідників «українського сепаратизму» можна відзначити С. Бабуріна, О. Дугіна, М. Ульянова та ін. Натомість більшість праць цих авторів грунтуються на ідеях російського імпераілізму й шовінізму і мають відверто пропагандистський характер. У сучасній українській етнополітології та етноконфліктології проблеми сепаратизму переважно розглядаються крізь призму української національної ідеї, побудови незалежної держави, аналізу причин, що призводять до появи на теренах сучасної України сепаратистських настроїв. Цими проблемами займаються М. Вівчарик, К. Вітман, О. Картунов, Л. Нагорна, І. Оніщенко, С. Римаренко та ін. [4].

У світі існує близько 5 тис. етносів, тож гіпотетичне самовизначення кожного 3 них утворить «клаптикову» політичну карту світу. На появу сепаратистських рухів також оперативно реагують сильні сусідні держави, які, виходячи 3 власних інтересів, підтримують або не підтримують сепаратистів, наприклад, можна згадати російсько-грузинський конфлікт 2008 р. 3 приводу самовизначення Південної Осетії й Абхазії, з одного боку, і самовизначення Косово - 3 іншого, адже ставлення провідних держав світу до цих випадків відрізнялося.

Виникнення сепаратистського руху можливе за наявності двох умов: 
1) дискримінації етнічної спільноти з боку державної влади; 2) формування активної політичної еліти, яка спроможна очолити цей рух.

Сепаратизм, із наукового погляду, прийнято поділяти на два види релігійний та етнічний. У першому випадку - рух релігійної меншини за відділення, а в другому - певного етносу.

За цілями, які переслідують певні групи людей, виділяють такі варіації сепаратизму:

- сецесія - рух, мета якого полягає у відділенні та утворенні нової незалежної держави (наприклад курдський сепаратизм у Туреччині, уйгурський

- у Китаї й Середній Азіі);

- іредентизм - сепаратизм, який спрямований на відділення та приєднання до іншої держави рух (наприклад рух за приєднання до Монголії автономного регіону Внутрішня Монголія в Китаї). До цього різновиду належить також анексія (насильницьке приєднання) територій іншої держави на підставі етнічної належності й/або попереднього володіння (наприклад анексія Криму Російською Федерацією);

- сепаратистські рухи, котрі прагнуть більшої автономії при збереженні регіону в складі держави (боротьба за розширення прав автономії Корсики у Франції).

Супутніми термінами, який часто вживається під час аналізу сепаратизму, $\epsilon$ «сецесія» й «сецесіонізм». Причому можна виділити два підходи залежно від того, яке поняття науковці визнають родовим, тобто більш широким, «сепаратизм» чи «сецесію».

Перший підхід - традиція визнавати саме «сепаратизм» родовим поняттям має більше прихильників.

Дослідниця сепаратизму В. Дівак дотримується такої схеми: сепаратизм є більш широким поняттям, оскільки позначає рух за відділення частини держави від іiі цілого й спрямований на досягнення різних цілей, а вже залежно від цих цілей виділено форми сепаратизму - сецесію, іредентизм, енозіс, деволюцію (автономізацію). На думку науковця, на відміну від сепаратизму, сецесія $\epsilon$ вужчим поняттям й означає вимогу формального виходу з держави, розриву звеязків із центральною політичною владою 3 боку будь-якої частини державного утворення на підставі до прагнення створення суверенної держави $[8$, c. 649].

Такий самий погляд на сецесію, сепаратизм й іредентизм спостерігаємо в працях інших українських науковців (Н. Романюк, О. Цебенка та ін).

Р. Нуруллін уважає, що сепаратизм є більш широким і менш визначеним поняттям, ніж сецесія, оскільки є багатозначним феноменом - це і прагнення, i рух, і переконання в необхідності відокремлення. Він проаналізував генезис семантичного наповнення поняття «сецесія», зауваживши, що «..відтінки значення слова сецесія змінювались у звеязку з історичним контекстом, але смислове ядро - «вихід й утворення нового інституту» - залишилося незмінним та присутне у всіх сучасних семантичних сполученнях 3 цим словом (уключаючи сецесію в мистецтві, економіці, медицині)». 
Що ж до співвідношення понять, то зазначено: «...сецесія, іредентизм i енозіс як форми сепаратизму, з логічного погляду, є більш вузькими термінами, звідси очевидно, що поняття “політичний сепаратизм” за обеємом набагато більше за них» $[13$, с. 217].

К. Пузирьов визначає сепаратизм як прагнення населення тієї чи іншої території до відокремлення з метою державного відособлення або приєднання до іншої держави [14, с. 137].

Другий niдxid. Інша дослідницька традиція визнає родовими поняття «сецесію» як вихід зі складу держави якоїсь іiі частини або «сецесіонізм» як сукупність ідей, які обгрунтовують курс суспільно-політичного руху, орієнтованого на відокремлення деякої території від наявної держави. У країнах пострадянського простору, на відміну від зарубіжних країн, саме за поняттям «сепаратизм» закріпилося значення руху до незалежності. Власне, так формується інший погляд на співвідношення сепаратизму, іредентизму й сецесії. В етнополітології сепаратизм чітко пов'язується 3 метою утворення незалежної держави, наприклад у визначенні, поданому В. Свтухом, зазначається, що «зазвичай, сепаратисти розглядають державу як інституцію (форму) національної самоорганізації, у якій етнічна гомогенність і культурний консенсус становлять ідеологічну основу для політичного й територіального відділення частини держави та утворення нового етнополітичного організму (держави)» [9, с. 284].

У зарубіжних науках досить широко використовуються обидва терміни - i «сепаратизм», і «сецесія», - але в цілому зарубіжні дослідники не розглядають питання стосовно того, що $є$ родовим поняттям. Науковці демонструють абсолютно протилежні думки про співвідношення сепаратизму, сецесї та іредентизму. Найчастіше оперують поняттям «сецесія», але вкладають у нього дещо різний зміст.

Т. Амброзіо розуміє сецесію широко, як «вимоги етнічної, національної або іншої спільноти, що історично склалася, «вивести» свою територію зі складу держави, частиною якої на сьогодні ця територія є» [1, p. 67]. Однак таке визначення $є$ дещо загальним.

А. Б’юкенен чітко пов’язує сецесію 3 виходом території разом із населенням 3-під контролю держави й створенням нової незалежної держави, влада якої поширюється на всю територію, що відокремилася, i на все іiі населення [2, р. 54].

Науковці (П. Фіала, М. Мареш, М. Стрміска) вважають, що у вузькому сенсі сепаратизм стосується створення держави, у тому числі на територіях кількох країн, у яких проживає відповідна етнічна група (Курдистан), у той час як розділення національної території однієї держави називається сецесіонізмом [20, с. 67].

Ця думка заслуговує на увагу, адже сепаратизм розуміється як певна ідея, як відцентровий рух, спрямований на утворення нової держави, а сецесіонізм як технологія виокремлення окремої території чи територій.

У світі виокремлюють шість регіональних різновидів сепаратизму: західноєвропейський (нараховує вісім проявів сепаратизму); східноєвропейський 
(13 проявів сепаратизму); ісламський (шість проявів сепаратизму); азіатський (14 проявів сепаратизму); африканський (шість проявів сепаратизму); американський (чотири прояви сепаратизму).

Західноєвропейський різновид сепаратизму (Корсика, Каталонія, Північна Ірландія, Країна Басків, Фландрія й Валлонія, Фарерські острови, Північний Кіпр) характеризується переважанням двох чинників - етноконфесійного та соціально-економічного. Вогнища сепаратизму в Західній Європі тривалий час перебувають у стані стійкої рівноваги. У регіоні переважає висока суспільна мобілізація населення, яка не виходить за межі «цивілізованої» політичної боротьби (за винятком Ольстера, Корсики й Країни Басків). Мета західноєвропейських сепаратистів, зазвичай, полягає не у створенні незалежної держави, а в досягненні максимальної національно-культурної, економічнополітичної автономії в рамках наявних нині державних кордонів. Основна частина населення без ейфорії сприймає розпливчасті перспективи самостійного існування. Комплексну ідентичність у європейців виробило усвідомлення своєї малої батьківщини як частини єдиної Свропи

До країн Свропи, у яких основним джерелом сепаратизму є лінгвістичний фактор, можемо віднести Іспанію, Велику Британію, Сербію та ін. Спільним для цих держав є наявність численних народностей, які розмовляють різними (часто неспорідненими) мовами й створюють для захисту своїх інтересів політичні партії та громадські організації. Одним із найбільш гострих випадків сепаратизму в Іспанії є країна Басків. У цій провінції 31959 р. існує ліворадикальна терористична організація ETA (Euzkadi Ta Azkatasuna, ETA, у перекладі з баскської мови - «Басконія та свобода»). Передусім, сепаратизм зумовлений утисненням басків із боку режиму Франсиско Франко заборонялися баскська мова, імена та національний прапор. Після смерті генералісимусу ситуація поступово змінилася: зараз Країна Басків має статус автономії, баскська мова - статус державної, а рівень життя в провінції перевищує середній по країні. Більше того, це єдина 3 усіх іспанських автономій, у бюджет якої нараховуються всі зібрані на іï території податки. Однак ЕTA продовжує наполягати на самовизначенні, хоча офіційно вважається, що їі підтримка в суспільстві постійно знижується. [12 ].

Ще одним регіоном із проявами сепаратизму в Іспанії є Каталонія. На відміну від басків, донедавна каталонці не вимагали незалежності регіону, проте наполягали на максимальній автономії й реалізували свої вимоги лише мирними методами. У 1979 р. Каталонія отримала власний уряд, а за результатами референдуму 2006 р., його повноваження були розширені. У 2017 р. сепаратистські рухи Каталонії почали вимагати незалежності й навіть провели референдум із цього приводу. Більшість каталонців проголосували за незалежність Каталонії, проте уряд Іспанії заблокував це рішення, після чого лідери сепаратистського руху змушені були покинути країну.

Автономного статусу в складі Іспанії також домоглися Валенсія, Галісія та Андалусія. Валенсійський націоналізм бере свій початок 31902 р., розділений на дві частини щодо питання національної ідентичності. Частина валенсійців ідентифікує себе з каталонцями та налаштовані радикально, а інша 
частина вважає, що каталонці намагаються нав'язати їм свою мову та культуру. В Іспанії існують також суспільні рухи за формування Великої Кастилї̈, у яку б увійшли регіони Кантабрія, Канталія-і-Леон, Ла-Ріоха та Кастилія-ла-Манча. Упродовж 80 років вимагають автономії в складі Іспанії Канарські Острови. У 1970-х рр. виголошувалась ідея берберської єдності, оскільки більшість населення островів - етнічні бербери.

Особливу гострою є проблема сепаратизму в Бельгії. Це пояснюється наявністю досить сильних розбіжностей між франкомовною частиною населення північної частини країни Валлонії та фламандцями, які розмовляють голландською мовою (ця група населення проживає в північній частині держави - Фландрії). Остання становить більшість населення Бельгії, однак перші півтора сторіччя існування держави французька мова була єдиною державною, а фламандська отримала такий статус лише в 1980 р. Центральним предметом конфлікту, який є причиною нового загострення політичної кризи, в останні роки, є статус двомовного виборчого й судового округу Брюссель-ХалВілворде. Цей округ - «гібридна цілісність», яка поєднує 19 комун регіону Брюссель і 35 комун від провінції Фламандський Брабант. Більшість його населення розмовляє французькою мовою, але він розміщений на території Фландрії, а його історична приналежність - предмет спору між фламандськими та валлонськими сепаратистами

Подібні причини мають і сепаратистські рухи в Італії. Розрив між аграрним Півднем та індустріально розвиненою Північчю значно більший, ніж у Бельгії. Ситуація в південних регіонах обтяжена діяльністю мафії. В Італії 3 1991 р. діє партія «Північна ліга» (або «Ліга Півночі»), яка виступає з гаслами федералізації країни та перегляду розподілу доходів на користь промислово розвиненої Півночі і iї відділення від слабшого Півдня. Багато експертів вважають перспективу перетворення Італії у федерацію досить реальною, оскільки «Північна ліга» має значний вплив у деяких регіонах (у Венеції та Ломбардії за неї голосують 30 \% виборців). У районах Південного Тіроля, які відійшли до Італії після Першої світової війни, є прибічники возз'єднання 3 Австрією. Більшість місцевого населення становлять етнічні німці, італійців постійно виживають. У 1950-1980-х рр. було навіть здійснено понад 300 терактів, але на сучасному етапі сепаратистські настрої реалізуються мирним шляхом. Власна сепаратистська партія є в кожному регіоні Італії. Так, автономії - фінансової, а в перспективі й політичної - вимагають середземноморські острови Сардинія та Сицилія, деякі мешканці провінції Венето вважають незаконним уключення Венеції до складу Італії в 1866 р. і вважають, що існує окрема венеційська мова, яка має бути визнана офіційною в регіоні.

Східноєвропейський різновид сепаратизму (Дагестан, Чечня, Придністров’я, Крим, Гагаузія, Косово, Македонія, Республіка Сербська в Боснії, Трансильванія, Крим, Донбас) охоплює колишні соціалістичні країни Східної та Центральної Європи й держави, які утворилися на території колишнього СРСР (крім чотирьох мусульманських республік Середньої Азії). Цей різновид вирізняється від західноєвропейського недавньої актуалізацією головних осередків сепаратизму (кінець 1980-х років) та прагненням сепаратистських 
рухів до повної незалежності, а не до автономії. Коріння конфліктів у Східній Європі, незважаючи на недавню актуалізацію, ідуть у колишні історичні епохи. Наприклад, зародження конфлікту в Боснії й Герцеговині між православними сербами та слов'янами-мусульманами відбулося ще за часів турецького панування (XV-XIX ст.), а бажання татар відновити власну державність починає свій відлік від припинення існування Казанського ханства в середині

XVI ст. Зауважимо, що конфлікти в Східній Європі призводять до втручання 3 боку інших держав і міжнародних організацій (ООН, НАТО, СС, РФ). Це пояснюється відносною близькістю вогнищ конфліктів до цих держав i загрозою їх безпеки [7].

У Східній Свропі існує низка невизнаних держав, що мають, проте, усі атрибути державності: Чечня (до 1999 р.), Абхазія, Придністровська Молдавська Республіка, Республіка Сербська в Боснії, так звані Донецька й Луганська народні республіки в Україні. Ці територіально-політичні утворення, маючи регулярні збройні формування, упевнено контролюють свою територію. Тут діють самопроголошені конституції, органи виконавчої й судової влади, проводяться парламентські вибори.

Якщо сепаратизм у високорозвинених країнах Європи розвивається в основному завдяки внутрішнім чинникам, то на постсоціалістичному просторі наростає роль міжнародного втручання, заохочення сепаратизму в інтересах більш сильних держав і транснаціональних структур. Найбільш яскраво роль геополітичного фактора в розпалюванні сепаратизму видно на прикладі колишньої Югославії, яка являла собою багатонаціональну державу, що складалась із шести республік і двох автономних країв у складі Сербії. Сдність держави забезпечувалася продуманою національною політикою, перебільшеною увагою до народів, які населяли федерацію, владою та силою їі лідера - Й. Броз Тіто, однопартійною системою та багаторівневою системою самоврядування. Першою від Югославії відокремилася іiі найрозвиненіша частина - Словенія. Уже в 1990 р. прийнято декларацію про повний державний суверенітет Словенії. Ця подія стала прецедентом для інших республік, які також виявили намагання створити незалежну державу. Подіі, які розвивались упродовж 1990-1995 рр., були драматичними, оскільки це був період міжетнічної війни в Югославію, яка стала віддзеркаленням багаторічної політики 3 метою створення єдиної держави. Балканський півострів через особливості свого геополітичного положення був i залишається у фокусі зіткнення інтересів різних держав Заходу й Сходу. Особливу увагу треба приділити албанському питанню, ця проблема має комплексний характер, оскільки вона є розповсюдженою: Сербія - проблема незалежності Косова, Македонія - проблема відносин між македонцями та албанцями тощо. Історична пам'ять і той факт, що албанці $є$ одним із найдавніших народів півострова, який проживає в його західній частині, $є$ першочерговим мобілізаційним фактором албанського націоналізму та іредентизму.

Розпад Радянського Союзу та його зникнення із політичної карти світу призвели до пожвавлення багатьох «заморожених» конфліктів, що мали міжнаціональний характер. До них можна віднести конфлікт у Придністров’і, 
Нагірному Карабасі та Грузино-Абхазький конфлікт. Значну роль у загостренні цих конфліктів відігравала РФ, яка таким чином намагалася втримати колишні республіки СРСР у зоні свого впливу. Росія була й залишається найвпливовішим актором у виникненні та розв'язанні всіх «заморожених» конфліктів на пострадянському просторі.

Одним із найбільш довготривалих $є$ конфлікт між Вірменією й Азербайджаном за Нагірний Карабах. Цей військовий конфлікт відбувався впродовж 1987-1994 рр. Нагірний Карабах - давня етнічна територія вірмен. Причиною конфлікту стала територіальна політика СРСР, що, як завжди, не враховувала етнічний фактор. Нагірний Карабах був включений до складу Азербайджанської РСР. Протистояння назрівало давно, але пролилася перша кров лише в 1988 р., що пов'язано з ослабленням центру i, як наслідок, неможливістю втримати етнонаціональні конфлікти на окраїнах СРСР. Війна супроводжувалася масовими етнічними чистками 3 обох боків. Азербайджанська армія, попри технічну та масову перевагу, зазнала поразки від напіввійськових партизанських формувань, із яких тоді складалася вірменська армія. У результаті конфлікту загинуло до 50000 осіб. Вірменія ж перемогла багато в чому завдяки підтримці Росії, унаслідок чого вона міцно закріпилась у iі зоні впливу. Конфлікт досі не вирішено, а лише «заморожено».

Час від часу він спалахує з новою силою, як то було у 2016 р., коли загинуло декілька військових з обох сторін.

Ще одним осередком конфлікту відразу після розпаду СРСР стало Придністров'я в Молдові. Геополітичне положення Придністров'я перетворює його у важливий елемент системи регіональної безпеки, оскільки торкається інтересів багатьох країн. Тут зосереджено значні промислові ресурси, проходять стратегічно важливі транспортні, енергетичні та торговельні шляхи сполучення, які $є$ невід'ємною складовою частиною економічного розвитку Східної Європи. Напружені відносини між придністровськими сепаратистами та молдовською елітою призвели до виникнення воєнних дій на території Молдови.

Окремої уваги заслуговують сепаратистські рухи на території Грузії. У серпні 2008 р. після збройного конфлікту незалежність Абхазії та Південної Осетії від Грузії визнано Росією, а пізніше - низкою інших держав. Визнання Росією незалежності Південної Осетії та Абхазії викликало резонанс на Заході. Різні політики й суспільні діячі зазначили, що це визнання не відповідає принципам міжнародного права, є порушенням територіальної цілісності та суверенітету Грузіі. Уряди ж Абхазії й Південної Осетії, які виступали за відділення та оголосили про свою незалежність, відкрито посилалися на прецедент Косово, постійно вказуючи на «геноцид» свого населення з боку грузинської влади. I хоча сьогодні Росія, схоже, не бажає прийняти ці дві республіки до складу своєї федерації, у результаті конфлікту створюється ситуація, що нагадує становище на Кіпрі: регіони, чию незалежність сьогодні визнає, мабуть, тільки РФ, ризикують бути фактично керованими з Москви, поки міжнародна геополітична ситуація не дасть змоги знайти стійку форму вирішення ситуації. 
Із 2014 р. вогнища сепаратизму після Революції Гідності спалахнули і в Україні. У Криму сепаратизм проявився у формі іредентизму (прагнення приєднатися до Російської Федерації), а на Донбасі - у формі сецесії (утворення невизнаних державних утворень).

Близькосхідний (ісламський) різновид (Курдистан, Гірський Бадахшану Таджикистані, пакистанська провінція Белуджистан, Південний Ємен, область Читтагонгу Бангладеш, вогнища сепаратизму на півночі Афганістану й на півдні Алжиру) панує в ісламських країнах Близького та Середнього Сходу, Північної Африки, Середньої й Південної Азії. Для цього типу сепаратизму характерна приналежність будь-яких протиборчих сторін до одного релігійнокультурного фундаменту - ісламу. При цьому вирішальне значення має фактор етнічної самосвідомості меншин, та придушення в національних державах їхніх одновірців. Приклади цього - конфлікти між шиїтами та сунітами в Іраку, між пуштунами та хазарійцями в Афганістані, між ісмаїлітами Гірського Бадахшана й рівнинними таджиками [11].

Азіатський різновид. Поширення цього різновиду сепаратизму обмежено Східною, Південно-Східною, Південною Азією. Серед вогнищ сепаратизму в регіоні виділяють індійські штати Джамму та Кашмір, Пенджаб, Наголенд, Ассам, північна Шрі-Ланка, області Карен і Шах у М“янмі (Бірма), південні Філіппіни, Східний Тимор й Ірма-Джая (західна частина Нової Гвінеї) в Індонезії, Тибет та Сіньцзян (Уйгуристан) у Китаї. Конфлікти в цьому регіоні мають коріння в доколоніальних часах, але відродилися після отримання країнами державної незалежності. У країнах із невисокими душовими доходами (Індія, Шрі-Ланка, М'янма) ризик сепаратизму для національних окраїн максимальний. Вогнища конфліктів цього різновиду відрізняються великою кількістю жертв, у тому числі й серед мирного населення.

Африканський різновид уключає прояви сепаратистських рухів у Південному Судані, провінції Кабінда в Анголі, Північному Сомалі, на Коморських Островах, у провінції Квазі-Наталь у ПАР, у Руанді й Бурунді. Багато в чому цьому різновиду відповідає все те, що сказано щодо азіатського різновиду. Відмінності простежено в більш пізньому досягненні країнами регіону державної незалежності й, відповідно, у більш пізньої актуалізації вогнищ конфліктів, що сталася, зазвичай, після відходу з континенту колоніальних держав. Крім того, в Африці відзначається менша, ніж в Азії, організованість сепаратистських рухів, що позначається на їх активності. Цей факт пояснюється тим, що більшість африканських етносів досі перебуває на племінній стадії розвитку. Тут звичайна міжплемінна ворожнеча, що перешкоджає створенню великих етнічних угруповань, які б могли висунути сепаратистські вимоги.

Міжетнічні зіткнення між племенами хуту й тутсіу Руанді та Бурунді, багаторічна громадянська війна в Демократичній Республіці Конго (колишній Заїр), недавні запеклі зіткнення в Ліберії та Сьєрра-Леоні стали символами нічим не виправданої, майже тваринної жорстокості. Тільки в Руанді конфлікт забрав життя понад 1,5 млн життів.

Американський різновид сепаратизму представлений у канадській провінції Квебек, мексиканському штаті Чьяпас, на території Гренландії 
(самоврядна територія Данії), на острові Невіс у складі Федерації Сен-Кітс і Невіс. Перші сепаратистські настрої на континенті мали більше поширення. Саме вони привели до розпаду Великої Колумбії (1830р.) та Сполучених провінцій Центральної Америки (1838-1839 рр.), виділення Уругваю зі складу Аргентини (1828p.) та Панами 3 Колумбії (1903р.). Сепаратистські рухи зумовили й громадянську війну в США (1861-1865pp.), яку можна розглядати як невдалу спробу виходу групи південних штатів, які утворили суверенну конфедерацію, зі складу єдиної держави. Наразі американський регіон, порівняно з іншими частинами планети, визначається найменшим поширенням сепаратизму (усього чотири яскраво виражені вогнища). Існує декілька причин цього феномену: 1) переселенський характер держав Нового Світу, котрий практично виключає непереборні й глибокі протиріччя між конфесійними та етнічними групами емігрантів; 2) роз'єднаність і нечисленність корінного населення - індіанців й ескімосів; 3) домінування в рамках кожної країни лише однієї етнічної групи переселенців. У більшості латиноамериканських країн цією групою були іспанці, у Бразилії - португальці, у Північній Америці британці. Єдиною країною, колонізованою двома рівноправними націями, була Канада. Результат - чотири століття боротьби між англо- й франко-канадцями за чільне місце в країні, яка породила найсерйозніше на сьогодні вогнище сепаратизму в Новому Світі - Квебек. Особливого загострення боротьба за відділення цієї канадської провінції набула після того, як сепаратистська квебекська партія в 1994 р. виграла місцеві вибори та прийшла до влади. Прихильники федерації 3 мінімальним відривом випередили франкоканадських націоналістів (50,6 \% на 49,4 \% відповідно). Проте малий розрив у результатах референдуму дає підставу стверджувати, що сепаратистські ідеї користуються великою популярністю [9].

У цілому ж як зауважує Н.Горло, що для позначення відцентрових тенденцій у суспільствознавчих науках застосовується розгалужена система понять, тлумачення яких іноді мають суттєві відмінності не тільки у представників різних національних шкіл, але й серед співвітчизників. На ії думку, у виробленні конвенціонального знання щодо сутності сепаратизму, іредентизму, сецесіонізму і сецесії має бути зацікавлена не тільки наукова спільнота, але й самі політичні а́ктори - держави, наднаціональні утворення, меншини. Поки ж ці поняття цілком не усталені в офіційних документах, вони стають інструментами політичної казуїстики [6,с 114].

\section{3. ВИСНОВКИ ТА ПЕРСПЕКТИВИ ПОДАЛЬШИХ ДОСЛІДЖЕНЬ}

Отже, як показує світовий досвід, сепаратизм має глибокі історичні корені, що пов'язані з існуванням суперечності між історичними традиціями взаємодії держав на принципах державного суверенітету й непорушності кордонів, 3 одного боку, та принципом права націй на самовизначення, який утвердився в практиці міжнародних відносин i передбачає можливість формування незалежних держав. У цілому ж зауважимо, що для позначення відцентрових тенденцій у суспільствознавчих науках застосовують розгалужену систему 
понять, тлумачення яких іноді мають суттєві відмінності не лише в представників різних національних шкіл, але й серед співвітчизників.

На нашу думку, у виробленні конвенціонального знання щодо сутності сепаратизму, іредентизму, сецесіонізму й сецесії має бути зацікавлена не лише наукова спільнота, але й самі політичні автори (держави, наднаціональні утворення, меншини). Поки ж ці поняття цілком не усталені в офіційних документах, вони стають інструментами політичної казуїстики. Така суперечність доволі часто має бути наслідком домінування принципу національного самовизначення над інтересам національної безпеки держав, до складу яких входять території з етнічними анклавами. Можна стверджувати, що на особливості зародження та на розвиток осередків сепаратизму у світі накладає відбиток політико-географічне положення території. До вироблення конкретних рекомендацій стосовно зниження ризиків сепаратизму може призвести розуміння механізмів цього впливу. Незважаючи на значну кількість наукових праць, що стосуються проблем сепаратизму, поки що в Україні бракує комплексних наукових досліджень цього явища. Мало уваги приділяється цій проблематиці й у рамках суспільної географії.

\section{СПИСОК ВИКОРИСТАНИХ ДЖЕРЕЛ}

1. Ambrosio, Т. (2001). Irredentism: ethnic conflict and international politics. Westport: Praeger Publ., 226 p.

2. Buchanan, A. (1991). Secession: the Morality of Political Divorce from Fort Sumter to Lithuania and Quebec. Boulder, Colorado: Westview Press, 192 p.

3. Баранов, А. В. (2005). Сепаратизм в современном мире: политико-территориальный аспект. Человек. Сообщество. Управление, № 3, С. 108-123.

4. Вітман, К. М. (2014). Особливості процесу сепаратизації в Україні. Актуальні проблеми політики, Вип. 53, С. 19-28.

5. Горенкин, В. (2001). Сепаратизм: феномен и понятие. Ученые записки Таврического национального университета им. В. И. Вернадского. Серия «Политические науки», Т. 14 (53), № 1, С. 34-39.

6. Горло Н. В Функціональні та концептуальні моделі політики іредентизму: дисертація д. політ. н.: 23.00.02 - політичні інститути та процеси. Запоріжжя, Львів, 2019. 486 с.

7. Горчаков, Л. О. (2009). Історичне коріння етносеператизму як об'єкта політологічних досліджень. Наукові пращі: наук.-метод. журн. Миколаїв, Т. 110. Політологія,

№ 97, С. 66-71.

8. Дівак, В. В. (2008). Форми й основні етапи сепаратистських рухів. Держава і право: зб. наук. праць. Юридичні і політичні науки. Київ: Ін-т 439 держави і права ім. В. М. Корецького НАН України, Вип. 40, С. 648-654.

9. Этногеография: учеб.-метод. комплекс для студентов, обучающихся по спец. «География». Горно-Алтайск: РИО ГАГУ, 2009. 68 с.

10. Свтух, В. Б. (2012). Етнічність: енциклопедичний довідник/Нац. пед. ун-т імені М. П. Драгоманова, Центр етноглобалістики. Київ: Фенікс, 396 с.

11. Европейский сепаратизм: Испания - первый кандидат в Европе на распад по «лоскутному сиенарию». URL: http://www.imperiya.by/politics 3-8357.html.

12. Маслова, Н. М. (2017). Етногеографія: навч.-метод. посіб. для студентів геогр. спец. вищ. пед. навч. закл. Кропивницький, 116 с.

13. Нуруллин, Р. М. (2010). Понятие сецессии в политической науке. Ученые записки Казанского государственного университета, Т. 152, кн. 1: Гуманитарные науки. С. 212-221.

14. Пузырев, К. С. (2010). Сепаратизм как политическое явление. Территория новых возможностей. Вестник Владивостокского государственного университета экономики и сервиса, Вып. № 3 (7), С. 133-143.

15. Schraeder, P. J. (2007). From Irredentism to Secession. The Decline of Pan-Somali Nationalism. 
After Independence: Making and Protecting the Nation in Postcolonial and Postcommunist States / Lowell,

W. Barrington, Editor / The University of Michigan Press. URL:

http://www.press.umich.edu/pdf/0472098985-ch5.pdf (last accessed: 04.07.2017)

16. Тураев, В. А. (2004). Этнополитология. Москва: Логос, 388 с.

17. Татаренко, Т. М. (2003). Регіоналізм і питання політичної трансформації державнотериторіального улаштування (на прикладі Бельгії та Італії). Нова 463 парадигма: альманах наукових пращь. Запоріжжя, Вип. 30, С. 177-185.

18. Horowitz, D. L. (1991). Irredentas and Secessions: Adjacent Phenomena, Neglected Connections (Chapter 1). Irredentism and International Politics / N. Chazan (ed.). Boulder, CO: Lynne Rienner Publ., 1991. P. 9-22.

19. Цебенко, О. О. (2011). Ідеологічні засади сепаратизму. Актуальні проблеми міжнародних відносин/Київський національний університет ім. Т. Шевченка, Інститут міжнародних відносин. Київ: Ін-т міжнар. відносин, Вип. 99, ч. 2. С. 90-94.

20. Fiala, P., Mareš, M., Strmiska, M. (2003). Organizace etnických menšin a prosazování jejich zájmů. Sbornik praci fakulty sociálních studii Brněnské univerzity. Sociální studia, 9, 2003. S. 65-86. URL: http://socstudia.fss.muni.cz/dokumenty/080305095650.pdf (last accessed: 20.01.2018).

\section{THE SUDDEN APPEARANCE OF SEPARATISM AND ITS ROLE IN THE DOMESTIC POLITICAL PROCESSES OF THE POLY-ETHNIC STATES}

The author analyzes the conceptual approach to the study of separatism, which involves a territorial-political movement, the purpose of which is to separate part of its territory from the country and create an independent state. Separatism breaks the unity, sovereignty and territorial integrity of the state, the principle of inviolability of borders. The concept essence of the phenomenon under study has been clarified. The essence of the concepts of «separatism» and «politics of separatism» is defined, the specifics of separatism in the context of other ethno-unification and ethno-separation movements are revealed. Functional models of separatism policy are distinguished, taking into account the nature of the strategic goals of the subjects of separatism and the type of prevailing international relations during a certain historical period. The essence of the dual nature of separatism, its specificity at two levels domestic and international - is revealed. Attention is drawn to regional varieties of separatism: Western European (there are 8 manifestations of separatism); Eastern European (13 manifestations of separatism); Islamic (6 manifestations of separatism); Asian (14 manifestations of separatism); African (6 manifestations of separatism); American (4 manifestations of separatism). It is proven that separatism has deep historical roots, which are connected with the existence of contradictions between the historical traditions of the interaction of states on the principles of state sovereignty and the inviolability of borders on the one hand, and the principle of the right of nations to self-determination, established in the practice of international relations and providing for the possibility of formation of independent states. Centers of separatism in the world imprint the political and geographical position of the territory. Making specific recommendations for reducing the risks of separatism can lead to an understanding of the mechanisms behind this impact.

Key words: separatism, separatist movement, ethnic conflicts, secession, irredentism, ethnic community, national identity.

\section{REFERENCES}

1. Ambrosio, T. (2001). Irredentism: ethnic conflict and international politics. Westport: Praeger Publ., 226 p.

2. Buchanan, A. (1991). Secession: the Morality of Political Divorce from Fort Sumter to Lithuania and Quebec. Boulder, Colorado: Westview Press, 192 p.

3. Baranov, A. V. (2005). Separatyzm v sovremennom myre: polytyko-terrytoryalnyi aspekt [Separatism in the Modern World: Political-Territorial Aspect]/ Chelovek. Soobshchestvo. Upravlenye № 3. PP. 108-123 (in Russian).

4. Vitman, K. M. (2014). Osoblyvosti protsesu separatyzatsii v Ukraini. Aktualni problemy polityky 
[Features of the Separation Process in Ukraine], Vyp. 53, P. 19-28 (in Ukrainian).

5. Horenkyn, V. (2001). Separatyzm: fenomen y poniatye [Separatism: Phenomenon and Concept]. Uchenye zapysky Tavrycheskoho natsyonalnoho unyversyteta ym. V. Y. Vernadskoho. Seryia «Polytycheskye nauky», T. 14 (53), № 1, P. 34-39 (in Russian).

6. Horchakov, L. O. (2009) Istorychne korinnia etnoseperatyzmu yak obiekta politolohichnykh doslidzhen [The historical roots of ethnosperatism as an object of political science] / Naukovi pratsi: Naukovo-metodychnyi zhurnal. Mykolaiv, T. 110. Politolohiia, № 97,

P. 66-71 (in Ukrainian).

7. Horlo N. V. Functional and conceptual models of the irredentism policy. - On the rights of the manuscrip. Thesis for Doctoral Degree in Political Science, speciality 23.00.02 - Political Institutions and Processes. Zaporizhzhia, Lviv, 2019. 486 p.

8. Divak, V. V. (2008). Formy y osnovni etapy separatystskykh rukhiv [Forms and main stages of separatist movements]. Derzhava i pravo: zbirnyk naukovykh prats. Yurydychni i politychni nauky. Kyiv: In-t 439 derzhavy i prava im. V. M. Koretskoho NAN Ukrainy, Vyp. 40,

P. 648-654 (in Ukrainian).

9. (2009). Etnoheohrafyia: uchebno-metodycheskyi kompleks dlia studentov, obuchaiushchykhsia po spetsyalnosty "Heohrafyia» [ Ethnography: educational and methodological complex for students studying in the specialty «Geography»]. Horno-Altaisk: RYO HAHU, 68 p. (in Russian).

10. Yevtukh, V. B. (2012). Etnichnist: entsyklopedychnyi dovidnyk [Ethnicity: encyclopedic reference book]; Nats. ped. un-t imeni M.P. Drahomanova, Tsentr etnohlobalistyky. Kyiv: Feniks, 396 p. (in Ukrainian).

11. Evropeiskyi separatyzm: Yspanyia - pervyi kandydat v Evrope na raspad po «loskutnomu stsenaryiu» [European separatism: Spain is the first candidate in Europe to break up in a «patchwork scenario»]. URL: http://www.imperiya.by/politics 3-8357.html. (in Russian).

12. Maslova, N. M. (2017). Etnoheohrafiia: Navchalno-metodychnyi posibnyk dlia studentiv heohrafichnykh spetsialnostei vyshchykh pedahohichnykh navchalnykh zakladiv [Ethnography: Educationalmethodical manual for students of geographical specialties of higher pedagogical educational institutions] / N. M. Maslova. Kropyvnytskyi, 116 p. (in Ukrainian).

13. Nurullyn, R. M. (2010). Poniatye setsessyy v polytycheskoi nauke [The concept of secession in political science]. Uchenye zapysky Kazanskoho hosudarstvennoho unyversyteta.

T. 152, kn. 1. Humanytarnыe nauky. P. 212-221 (in Russian).

14. Puzyrev, K. S. (2010) Separatyzm kak polytycheskoe yavlenye. Terrytoryia novykh vozmozhnostei [Separatism as a political phenomenon. The territory of new opportunities.]. Vestnyk Vladyvostokskoho hosudarstvennoho unyversyteta эkonomyky y servysa. Vypusk № 3 (7).

P. 133-143 (in Russian).

15. Schraeder, P. J. (2017). From Irredentism to Secession. The Decline of Pan-Somali Nationalism. After Independence: Making and Protecting the Nation in Postcolonial and Postcommunist States / Lowell W. Barrington, Editor / The University of Michigan Press. URL: http://www.press.umich. edu/pdf/0472098985-ch5.pdf (last accessed: 04.07.2017)

16. Turaev, V. A. (2004). Etnopolytolohyia [Ethno-political science]. Moskva: Lohos, 388 p. (in Russian).

17. Tatarenko, T. M. (2003). Rehionalizm i pytannia politychnoi transformatsii derzhavnoterytorialnoho ulashtuvannia (na prykladi Belhii ta Italii) [Regionalism and the issues of political transformation of the state-territorial arrangement (for example, Belgium and Italy).]. Nova 463 paradyhma: Almanakh naukovykh prats. Zaporizhzhia, Vyp. 30, P. 177-185 (in Ukrainian).

18. Horowitz, D. L. (1991). Irredentas and Secessions: Adjacent Phenomena, Neglected Connections (Chapter 1). Irredentism and International Politics / N. Chazan (ed.). Boulder, CO: Lynne Rienner Publ., R. 9-22.

19. Tsebenko, O. O. (2011). Ideolohichni zasady separatyzmu [Ideological foundations of separatism]/ Aktualni problemy mizhnarodnykh vidnosyn / Kyivskyi natsionalnyi universytet im.

T. Shevchenka, Instytut mizhnarodnykh vidnosyn. K.yiv: In-t mizhnar. Vidnosyn, Vyp. 99, ch. 2, P. 90-94 (in Ukrainian).

20. Fiala, P., Mareš, M., Strmiska, M. (2018). Organizace etnických menšin a prosazování jejich zájmů. Sborník prací fakulty sociálních studií Brněnské univerzity. Sociální studia. 9, 2003. S. 65-

86. URL: http://socstudia.fss.muni.cz/dokumenty/080305095650.pdf (last accessed: 20.01.2018). 